\title{
Evaluation of Some Promising Sugarcane Varieties for Infestation with Two Sugarcane Borers, Yield and Quality under Different Row Spacing in Luxor Governorate, Egypt
}

\author{
Fahmy, A.M. ${ }^{*}$, A.S.S. Desoky ${ }^{2}$, M.O.A. Galal $^{3}$ \\ ${ }^{1}$ Plant Protection Dept., Fac. Agri. and Natural Resources, Aswan University, Egypt \\ ${ }^{2}$ Plant Protection Dept., Fac. Agri., Sohag University, Egypt. \\ ${ }^{3}$ Agron. Dept. Sugar Crop Res. Inst., Agric. Res. Cent., Giza, Egypt.
}

*Corresponding Author: Fahmy, A.M., Plant Protection Dept., Fac. Agri. and Natural Resources, Aswan University, Egypt

\begin{abstract}
The experiment was conducted at El-Mattana Research Station (latitude of $25.25^{\circ} \mathrm{N}$ and longitude of $32.31^{\circ}$ E), Agricultural Research Center, Luxor Governorate, Egypt on a plant cane in 2017/18 and its $1^{\text {st }}$ ratoon in 2018/19 to evaluate the susceptibility of five promising sugarcane varieties viz. G.2004-27, G.84-47, G.2003-47, G.99-103 and C.57-14 compared to the commercial G.T.54-9 variety for infestation with two sugarcane borers (Sesamia cretica and Chilo agamemnon), yield and quality under three inter-row spacing (80, 100 and $120 \mathrm{~cm}$ ).The studied combinations were randomly distributed in a randomized complete block design in a split-plot distribution, with three replications, where, inter-row spacing were allocated in the main plots, while sugarcane varieties were randomly distributed in the sub-plots. The results indicated that increasing inter-row spacing from 80 to $120 \mathrm{~cm}$ led to a significant reduction in dead hearts\%, bored stalks\%, bored joints, girdled stalks\%, mean no. holes/joint, mean no. holes/infested joint and mean no. holes/stalk in the plant cane and $1^{\text {st }}$ ratoon crops. While, the quality and yield traits (brix\%, sucrose\%, sugar recovery\%, cane and sugar yield/ton per ha) recorded the highest values when sugarcane grown in rows $100 \mathrm{~cm}$ in the plant cane and $1^{\text {st }}$ ratoon crops. Moreover, insignificant difference was found between 80 and $100 \mathrm{~cm}$ interrow spacing in the brix\% and cane yield in the plant cane. The promising sugarcane variety G.2004-27 was highest tolerance in all studied measurements of infestation by S.cretica and C. agamemnon in both seasons. Also, it recorded the highest values for cane and sugar yield /ton per ha in the plant cane and $1^{\text {st }}$ ratoon crop. The promising sugarcane variety G.2003-47 showed the significant superiority in the quality traits.
\end{abstract}

Under conditions of this investigation, the promising sugarcane variety G.2004-27 was highest tolerance in all studied measurements of infestation by S.cretica and C. agamemnon in both seasons. Also, it recorded the highest values for cane and sugar yield $/$ ton per ha in the plant cane and $1^{\text {st }}$ ratoon crop.

Keywords: sugarcane borers, Sesamia cretica, Chilo Agamemnon, row spacing, sugarcane varieties.

\section{INTRODUCTION}

Sugarcane plant is the main for sugar production in Egypt, its cultivated area about 320,000 fed. most them are in Upper Egypt. Sugarcane is severely attacked by two species of Lepidoptera. Larvae of the pink borer, Sesamia cretica Led. (Lepidoptera: Noctuidae) represents potential threat to sugarcane grown in upper and middle Egypt. It has been historically categorized as a shoot borer which enters shoot at ground level, eat young tissue and destroy the growing-point, thereby, causing the formation of characteristic "dead heart". The damage caused by Sesamia depends on the ability of affected plants to compensate for "dead heart" by production new shoots. The second species is the stalk borer, Chilo agamemnon Bles. (Lepidoptera: Pyralidae). It is the most destructive and potentially chronic species that attacks sugarcane. It is a pest on Poaceae crops in tropical and subtropical regions and chiefly attacks corn, sugarcane and rice. (El-Sherif, 1962). Lesser sugarcane stalk borer, $C$. agamemnon Bles., (Lepidoptera: Pyralidae) shows different symptoms of infestation as circular tunnels, infested joints and girdled stalks. This insect causes reductions in sugarcane yield, brix \% and sucrose\% (Tohamy, 1999). Damages of this pathogen depend severely on its incidence, as well as on the susceptibility of cane genotypes. Elwan et al. (2008) showed that, the infestation with $C$. 
agamemnon were varied in both autumn plant and $1^{\text {st }}$ ratoon, the infestation reduced in sugarcane plants cultivated at wide spaces $(100 \mathrm{~cm})$ than those cultivated at narrow spaces $(80 \mathrm{~cm})$. Salman $e t$ al. (2014) found that significant differences among sugarcane genotypes, where G.T.54-9 and G.2003-47 were the most susceptible ones in the incidence of infestation (bored stalks \%), intensity of infestation (bored joints \%) and girdled stalks \%, while G.98-28 variety was the least susceptible. Galal et al. (2017) mentioned that the commercial sugarcane variety G.T.54-9 recorded the highest percentages of infestation with $C$. agamemnon, in both seasons. Whereas promising sugarcane variety G.2003-47 recorded the lowest percentage of infestation with $C$. agamemnon in both seasons. However, the variance between the two promising genotypes namely G.2003-47 and G.2003-49 in the studied traits was mostly insignificant. Fahmy et al. (2017) showed that the sugarcane varieties differed significantly in their susceptibility to C. agamemnon infestation. The highest bored stalks\% was observed in G.2003-47 and G.T.54-9 varieties during the first and second season respectively. Mean while the lowest bored stalks\% was recorded with $\mathrm{Ph} 8013$ variety in both seasons. Mehareb et al. (2018) revealed that significant differences among sugarcane genotypes in susceptibility to the lesser sugarcane borer, C. agamemnon infestation measured as bored stalk $\%$ and bored joints $\%$ in the two studied seasons.

Yield potential of a variety can be achieved by manipulating agronomic practices. Among the various agronomic managements, row spacing influences the productivity of sugarcane by maintaining optimum stalk population per unit area. Planting geometry plays an important role in water use efficiency, interception of solar radiation and evaporation. Row spacing ensures more uniform allocation of plants in an area and makes canopy of plant more efficient in intercepting radiant energy. In Egypt, the commercial cane variety 'G.T.54-9' occupies most of the area planted with sugarcane. Recently, Sugar Crops Research Institute developed a lot of promising varieties of sugarcane, among them G.2004-27, G.84-47 and G.2003-47. The newly bred varieties showed variable response to different agronomic practices. In this respect, El-Geddawy, et al. 2015 \& Galal, et al. 2017 and ElBakry (2018) revealed that the promising sugarcane variety 'G.2003-47'showed the significant superiority in juice quality traits. El-Geddawy, et al. (2002) and Abd El-Lattief (2016) found that narrow inter-row spacing $(100 \mathrm{~cm})$ produced higher number of millable canes, cane and sugar yields compared to the other inter-row spacing $(120$ And $140 \mathrm{~cm})$. They added that 'F.153' variety produced the highest number of millable cans and cane yield, while 'G.T.54-9' had the highest sugar recovery $\%$. There is a contradiction regarding the effect of row spacing on the quality parameters such as brix, sucrose content and CCS (Sharar et al., 2000 and Asokan et al., 2005) but Pawar et al., (2005) supported the view that wider row spacing improved the sucrose content and commercial cane sugar percentage.

Rapid change in weather conditions requires us to follow up the development of sugarcane varieties for insect infestations, especially borer insects under all agricultural conditions from time to time. Therefore, the present study was initiated evaluate the performance of five promising sugarcane varieties compared to the commercial variety for infestation by sugarcane borers, yield and their quality under three inter-row spacing

\section{MATERials AND Methods}

The experiment was conducted at El-Mattana Research Station (latitude of $25.25^{\circ} \mathrm{N}$ and longitude of $32.31^{\circ}$ E), Agricultural Research Center, Luxor Governorate, Egypt on a plant cane in 2017/18 and its $1^{\text {st }}$ ratoon in 2018/19 to evaluate the susceptibility of five promising sugarcane varieties viz. G.200427, G.84-47, G.2003-47, C.57-14 and G.99-103 compared to the commercial G.T.54-9 variety for infestation by sugarcane borers ( $S$. cretica and $C$. agamemnon), yield and quality under three interrow spacing $(80,100$ and $120 \mathrm{~cm})$. Sugarcane varieties were planted in the $2^{\text {nd }}$ week of March using two rows of three-budded cuttings in planting. However, management of the first ratoon crop started during the $3^{\text {rd }}$ week of March after harvesting of the plant cane.

The studied combinations were randomly distributed in a randomized complete block design in a split-plot distribution, with three replications, where, inter-row spacing was allocated in the main plots, while sugarcane varieties were randomly distributed in the sub-plots. The sub-plot area was 60 
$\mathrm{m}^{2}$ (including 15, 12 and 10 rows in case of spacing them at 80,100 and $120 \mathrm{~cm}$, respectively, and 5 $m$ in length).

Nitrogen fertilizer was applied as urea $(46 \% \mathrm{~N})$ at the rate of $547 \mathrm{~kg} \mathrm{~N} / \mathrm{ha}$, which was split into two equal doses in the plant cane (after the $1^{\text {st }}, 2^{\text {nd }}$ hoeing and 30 days later, i.e. 45,75 and 105 days from planting). Nitrogen given to the first ratoon crop was split into two doses; 30 days after harvesting of the plant cane and 30 days later. Phosphorus fertilizer was added during land preparation at $143 \mathrm{~kg}$ $\mathrm{P}_{2} \mathrm{O}_{5} /$ ha as calcium super phosphate $\left(15 \% \mathrm{P}_{2} \mathrm{O}_{5}\right)$, meanwhile, potassium fertilizer was added at $114 \mathrm{~kg}$ $\mathrm{K}_{2} \mathrm{O} /$ ha as potassium sulphate $\left(48 \% \mathrm{~K}_{2} \mathrm{O}\right)$ once, with the first $\mathrm{N}$-dose. The other agronomic practices for growing sugarcane were done as recommended by the Sugar Crops Research Institute.

\subsection{Evaluation of Susceptibility of Promising Sugarcane Varieties to Infestation by Two Sugarcane Borers under Three Inter-Row Spacing.}

\subsubsection{Pink Borer, S. cretica:}

Dead hearts were surveyed for each variety from three replicates at 15 days intervals from April 21 to July 5, 2017 and form April 15 to June 29, 2018 for plant cane and $1^{\text {st }}$ ratoon, respectively. The percentage of dead hearts was counted according to the following equation:

Dead hearts $\%=$ No. dead hearts $/$ No. examined plant $\times 100$.

\subsubsection{Stalk Borer, C. agamemnon:}

Samples of 20 stalks were taken randomly from the middle rows of three replicates for each variety from July 15 and every month intervals up to harvest time at March 15, 2018 and 2019 for both plant cane and $1^{\text {st }}$ ratoon, respectively. Cane stalks were stripped, cleaned and examined for various noticeable sign infestation with $C$. agamemnon using the following formula according to Mendes, et al. (1980):

- Bored stalks Percentage $($ infestation incidence $)=$ No. of bored stalks $/$ No. of examined stalks $\times$ 100.

- Bored joints Percentage (infestation intensity) $=$ No. of bored joints / No. of examined joints $\times 100$.

- Girdled stalks Percentage $=$ No. of girdled stalks $/$ No. of examined stalks $\times 100$.

- Mean No. of holes / joint = No. of holes / No. of examined joints.

- Mean No. of holes / bored joint = No. of holes / No. of examined bored joints.

- Mean No. of holes / stalk = No. of holes / No. of examined stalks.

\subsection{Evaluation of Some Promising Sugarcane Varieties to Juice Quality Characteristics and Yield under Three Inter-Row Spacing}

A representative sample of 20 millable canes from each plot was taken at random, stripped, cleaned and squeezed. The primary juice was extracted by electric pilot mill screened and mixed thoroughly. One liter of juice was taken in glass cylinder to estimate juice quality characteristics.

Total soluble solids (TSS \%) in cane juice (Brix percentage) was determined in the laboratory using brix hydrometer standardized at $20^{\circ} \mathrm{C}$.

- Sucrose percentage was determined using Sacharemeter according to A.O.A.C. (1995).

- Sugar recovery percentage it was calculated as follows:

- Sugar recovery $\%=$ [sucrose $\%-0.4$ (brix $\%$ - sucrose $\%) \times 0.73]$.

- Where $\mathrm{B}=$ Brix reading, $\mathrm{S}=$ Sucrose percentage, 0.4 and 0.73 constants. Yadav and Sharma (1980).

- Cane yield/ton per ha was determined from the fresh weight $(\mathrm{kg})$ of millable canes of each plot, which was converted into ton/ha.

- Sugar yield/ ton per ha was estimated as follows:

- Sugar yield (ton per ha) = cane yield (ton per ha) x sugar recovery \%. 
Evaluation of Some Promising Sugarcane Varieties for Infestation with Two Sugarcane Borers, Yield and Quality under Different Row Spacing in Luxor Governorate, Egypt

\subsection{Statistical Analysis}

The collected data as a split-plot design were statistically analyzed according to the procedures outlined by Snedecor and Cochran (1981). Means of significant variance were compared using LSD test at $5 \%$ level of probability.

\section{RESULTS AND DISCUSSION}

\subsection{Infestation by $S$. Cretica}

\subsubsection{Dead Hearts\%.}

Data in Table (1) showed that the dead hearts \% was significantly affected by inter-row spacing in the plant cane and $1^{\text {st }}$ ratoon crops. Growing sugarcane in rows of $120 \mathrm{~cm}$ decreased the dead hearts $\%$ by 2.72 and 0.64 in the plant cane and 3.69 and 0.75 in $1^{\text {st }}$ ratoon, respectively, compared with that recorded in planting sugarcane at 80 and/or $100 \mathrm{~cm}$ inter-row spacing.

The results indicated that the varieties differed significantly in their susceptibility to shoot borer measured as dead hearts in the plant cane and $1^{\text {st }}$ ratoon. Moreover, G.99-103 was the least susceptible variety to $S$. cretica attack recording the lowest dead hearts $\%(2.41$ and $1.70 \%)$ in the plant cane and $1^{\text {st }}$ ratoon, respectively, compared with the other varieties. However, the difference in dead hearts\% between G.99-103 and G.2004-27 varieties was insignificant, in the plant and $1^{\text {st }}$ ratoon. Such varietal differences among cane genotypes in dead hearts \% were reported by Eskandar, 1996 \& Eid, et al., 2005.

Dead hearts \% was significantly influenced by the interaction between the tested cane varieties and inter-row spacing in the plant cane and $1^{\text {st }}$ ratoon.

\subsection{Infestation by C. Agamemnon}

\subsubsection{Bored Stalk \% (Infestation Incidence \%)}

Data in Table (1) showed that the bored stalk \% was significantly affected by inter-row spacing in the plant cane and $1^{\text {st }}$ ratoon crops. Growing sugarcane in rows of $120 \mathrm{~cm}$ decreased the bored stalk $\%$ by 11.21 and $6.36 \%$ in the plant cane and 30.10 and $11.10 \%$ in $1^{\text {st }}$ ratoon, respectively, compared with that recorded in planting sugarcane at 80 and/or $100 \mathrm{~cm}$ inter-row spacing.

The results in table (1) indicated that, bored stalk $\%$ in both plant cane and $1^{\text {st }}$ ratoon significantly differed among varieties. In plant cane and $1^{\text {st }}$ ratoon. G.T.54-9 (commercial cane variety) exhibited the highest bored stalk \% recording 24.65 and $47.2 \%$, respectively. On the other hand, G.2004-27 was the most tolerant variety in the plant cane and $1^{\text {st }}$ ratoon recorded the lowest bored stalk $\%(8.08$ and $23.1 \%$ ) respectively. Based on, data of both plant cane and $1^{\text {st }}$ ratoon.

Table1. Infestation by S. cretica (dead heart\%) and C. agamemnon ( bored stalk \% and girdled stalk \%) of the tested sugarcane varieties as affected by inter-row spacing and their interactions, in the plant cane, PC (2017/18) and its $1^{\text {st }}$ ratoon crop, FR (2018/19).

\begin{tabular}{|c|c|c|c|c|c|c|}
\hline \multirow{2}{*}{ Treatments } & \multicolumn{2}{|c|}{ Dead heart\% } & \multicolumn{2}{|c|}{ Bored stalk\% } & \multicolumn{2}{|c|}{ Girdled stalk\% } \\
\hline & $\mathbf{P C}$ & FR & $\mathbf{P C}$ & FR & $\mathbf{P C}$ & FR \\
\hline \multicolumn{7}{|c|}{ Row spacing } \\
\hline $80 \mathrm{~cm}$ & 5.31 & 4.89 & 22.22 & 50.0 & 6.87 & 23.15 \\
\hline $100 \mathrm{~cm}$ & 3.23 & 1.95 & 17.37 & 31.0 & 3.64 & 10.19 \\
\hline $120 \mathrm{~cm}$ & 2.59 & 1.20 & 11.01 & 19.9 & 1.41 & 6.95 \\
\hline LSD at $5 \%$ level & 0.30 & 0.33 & 0.34 & 0.59 & 0.54 & 0.88 \\
\hline \multicolumn{7}{|c|}{ Sugarcane varieties } \\
\hline G.T.54-9 (V1) & 4.55 & 2.46 & 24.65 & 47.2 & 3.94 & 27.78 \\
\hline G.2004-27 (V2) & 2.50 & 1.70 & 8.08 & 23.1 & 1.82 & 7.41 \\
\hline G.84-47 (V3) & 3.25 & 2.53 & 21.72 & 28.7 & 4.55 & 9.26 \\
\hline G.2003-47 (V4) & 3.30 & 2.84 & 21.01 & 42.6 & 5.76 & 14.81 \\
\hline G.99-103 (V5) & 2.41 & 1.70 & 8.28 & 26.9 & 2.93 & 7.41 \\
\hline C.57-14 (V6) & 6.25 & 4.84 & 17.47 & 33.3 & 4.85 & 13.89 \\
\hline Mean & 3.71 & 2.68 & 16.87 & 33.63 & 3.98 & 13.43 \\
\hline LSD at $5 \%$ level & 0.59 & 0.29 & 0.51 & 1.83 & 0.54 & 1.42 \\
\hline
\end{tabular}


Evaluation of Some Promising Sugarcane Varieties for Infestation with Two Sugarcane Borers, Yield and Quality under Different Row Spacing in Luxor Governorate, Egypt

\begin{tabular}{|c|c|c|c|c|c|c|c|}
\hline \multicolumn{8}{|c|}{ Interaction } \\
\hline \multirow{6}{*}{$80 \mathrm{~cm}$} & V1 & 6.80 & 5.25 & 30.91 & 66.67 & 6.06 & 47.22 \\
\hline & $\mathrm{V} 2$ & 4.87 & 3.05 & 12.12 & 33.33 & 3.94 & 13.89 \\
\hline & V3 & 4.99 & 4.06 & 29.09 & 47.22 & 7.58 & 16.67 \\
\hline & V4 & 5.37 & 5.12 & 26.97 & 58.33 & 8.79 & 22.22 \\
\hline & V5 & 3.17 & 2.73 & 11.52 & 38.89 & 6.67 & 13.89 \\
\hline & V6 & 6.63 & 9.09 & 22.73 & 55.56 & 8.18 & 25.00 \\
\hline \multirow{6}{*}{$100 \mathrm{~cm}$} & V1 & 3.52 & 1.14 & 25.15 & 38.89 & 3.64 & 19.44 \\
\hline & V2 & 2.07 & 1.31 & 7.88 & 22.22 & 1.21 & 5.56 \\
\hline & V3 & 2.40 & 2.27 & 22.12 & 22.22 & 4.55 & 5.56 \\
\hline & V4 & 2.83 & 1.71 & 21.52 & 50.00 & 6.67 & 13.89 \\
\hline & V5 & 2.25 & 1.65 & 10.00 & 25.00 & 1.82 & 5.56 \\
\hline & V6 & 6.33 & 3.64 & 17.58 & 27.78 & 3.94 & 11.11 \\
\hline \multirow{6}{*}{$120 \mathrm{~cm}$} & V1 & 3.33 & 1.00 & 17.88 & 36.11 & 2.12 & 16.67 \\
\hline & V2 & 0.55 & 0.73 & 4.24 & 13.89 & 0.30 & 2.78 \\
\hline & V3 & 2.35 & 1.25 & 13.94 & 16.67 & 1.52 & 5.56 \\
\hline & V4 & 1.69 & 1.69 & 14.55 & 19.44 & 1.82 & 8.33 \\
\hline & V5 & 1.83 & 0.72 & 3.33 & 16.67 & 0.30 & 2.78 \\
\hline & V6 & 5.77 & 1.79 & 12.12 & 16.67 & 2.42 & 5.56 \\
\hline \multicolumn{2}{|c|}{ LSD at $5 \%$ level } & 1.02 & 0.51 & 0.89 & 3.18 & 0.94 & 2,47 \\
\hline
\end{tabular}

All the new promising varieties were less attacked by $C$. agamemnon than the commercial variety G.T.54-9. No variety appeared to be immune towards C. agamemnon infestation. In general, the obtaind results are in accordance with those reviewed by Eid, et al., 2005\& Galal, et al., 2017 and Fahmy, et al., 2017.

Bored stalk \% was significantly influenced by the interaction between the tested cane varieties and inter-row spacing in the plant cane and $1^{\text {st }}$ ratoon.

\subsubsection{Bored Joint \% (Infestation Incidence \%)}

Data in Table (2) showed that the bored joint \% was significantly affected by inter-row spacing in the plant cane and $1^{\text {st }}$ ratoon crops. Growing sugarcane in rows of $120 \mathrm{~cm}$ decreased the bored joint $\%$ by 1.0 and 0.47 in the plant cane and 2.89 and 1.2 in the $1^{\text {st }}$ ratoon crop, respectively, compared with that recorded in planting sugarcane at 80 and/or $100 \mathrm{~cm}$ inter-row spacing.

Data in table (2) indicated that, used varieties significantly differed in their susceptibility to borer attack measured as bored joints\% in both plant cane and $1^{\text {st }}$ ratoon. G.T.54-9 seemed to be the most susceptible variety to borer attack recording the highest bored joints $\%$ in both plant cane and $1^{\text {st }}$ ratoon (2.35 and 3.76\%) respectively. On the other hand, G.99-103 (in plant cane) and G.2004-27 (in $1^{\text {st }}$ ratoon) were the least infested varieties attack by $C$. agamemnon. In general, the obtained results are in accordance with those reviewed by Eid, et al., 2005 \& Galal, et al., 2017 and Fahmy, et al., 2017.

Bored joints $\%$ was significantly influenced by the interaction between the tested cane varieties and inter-row spacing in the plant cane and $1^{\text {st }}$ ratoon.

\subsubsection{Girdled Stalks \%.}

Data illustrated in Table (1) showed that the Girdled stalks \% was significantly affected by inter-row spacing in the plant cane and $1^{\text {st }}$ ratoon crops. Growing sugarcane in rows of $120 \mathrm{~cm}$ decreased the girdled stalks $\%$ by 5.46 and 2.23 in the plant cane and 16.2 and 3.24 in the $1^{\text {st }}$ ratoon, respectively, compared with that recorded in planting sugarcane at 80 and/or $100 \mathrm{~cm}$ inter-row spacing.

Girdled stalks \% differed significantly among the varieties in both plant cane and $1^{\text {st }}$ ratoon (Table 1). G.2003-47 variety exhibited the highest girdled stalks \% in the plant cane (5.76\%). While G.T. 54-9 was recorded the highest girdled stalks $\%(27.78)$ in the $1^{\text {st }}$ ratoon. This indicated that these varieties were the most susceptible varieties among the other used varieties in both plant cane and $1^{\text {st }}$ ratoon to stalk borer attack. On the contrary, the most tolerant varieties (least susceptible) in plant cane and $1^{\text {st }}$ ratoon was G.2004-27 variety recorded 1.82 and $7.41 \%$ respectively. In general, the obtained results are in accordance with those reviewed by Eid, et al., 2005 \& Galal, et al., 2017 and Fahmy, et al., 2017.

Girdled stalks \% was significantly influenced by the interaction between the tested cane varieties and inter-row spacing in the plant cane and $1^{\text {st }}$ ratoon. 
Evaluation of Some Promising Sugarcane Varieties for Infestation with Two Sugarcane Borers, Yield and Quality under Different Row Spacing in Luxor Governorate, Egypt

Table2. Infestation by C. agamemnon (bored joint \%, Mean no. holes / joint and Mean no. holes / infested joint) of the tested sugarcane varieties as affected by inter-row spacing and their interactions, in the plant cane, PC (2017/18) and its $1^{\text {st }}$ ratoon crop, FR (2018/19).

\begin{tabular}{|c|c|c|c|c|c|c|c|}
\hline \multirow{2}{*}{\multicolumn{2}{|c|}{ Treatments }} & \multicolumn{2}{|c|}{ Bored joint \% } & \multicolumn{2}{|c|}{ Mean no. holes/joint } & \multicolumn{2}{|c|}{$\begin{array}{l}\text { Mean no. holes/ } \\
\text { infested joint }\end{array}$} \\
\hline & & $\mathrm{PC}$ & FR & $\mathrm{PC}$ & FR & $\mathrm{PC}$ & FR \\
\hline \multicolumn{8}{|c|}{ Row spacing } \\
\hline \multicolumn{2}{|c|}{$80 \mathrm{~cm}$} & 1.98 & 3.92 & 0.023 & 0.062 & 1.33 & 1.67 \\
\hline \multicolumn{2}{|c|}{$100 \mathrm{~cm}$} & 1.45 & 2.23 & 0.016 & 0.034 & 1.23 & 1.42 \\
\hline \multicolumn{2}{|c|}{$120 \mathrm{~cm}$} & 0.98 & 1.03 & 0.011 & 0.015 & 1.20 & 1.34 \\
\hline \multicolumn{2}{|c|}{ LSD at $5 \%$ level } & 0.02 & 0.30 & 0.0003 & 0.001 & 0.10 & 0.12 \\
\hline \multicolumn{8}{|c|}{ Sugarcane varieties } \\
\hline \multicolumn{2}{|c|}{ G.T.54-9 (V1) } & 2.35 & 3.76 & 0.031 & 0.061 & 1.27 & 1.65 \\
\hline \multicolumn{2}{|c|}{ G.2004-27 (V2) } & 0.65 & 1.47 & 0.007 & 0.021 & 1.18 & 1.39 \\
\hline \multicolumn{2}{|c|}{ G.84-47 (V3) } & 1.87 & 2.16 & 0.026 & 0.034 & 1.30 & 1.55 \\
\hline \multicolumn{2}{|c|}{ G.2003-47 (V4) } & 1.83 & 2.92 & 0.023 & 0.048 & 1.27 & 1.60 \\
\hline \multicolumn{2}{|c|}{ G.99-103 (V5) } & 0.63 & 1.62 & 0.009 & 0.020 & 1.24 & 1.24 \\
\hline \multicolumn{2}{|c|}{ C.57-14 (V6) } & 1.50 & 2.41 & 0.003 & 0.036 & 1.27 & 1.42 \\
\hline \multicolumn{2}{|c|}{ Mean } & 1.47 & 2.39 & 0.017 & 0.037 & 1.26 & 1.48 \\
\hline \multicolumn{2}{|c|}{ LSD at 5\% level } & 0.04 & 0.31 & 0.0004 & 0.004 & NS & NS \\
\hline \multicolumn{8}{|c|}{ Interaction } \\
\hline \multirow{6}{*}{$80 \mathrm{~cm}$} & V1 & 3.06 & 6.32 & 0.042 & 0.101 & 1.30 & 1.77 \\
\hline & V2 & 0.99 & 1.87 & 0.012 & 0.026 & 1.28 & 1.57 \\
\hline & V3 & 2.52 & 4.12 & 0.034 & 0.064 & 1.29 & 1.67 \\
\hline & V4 & 2.46 & 4.19 & 0.031 & 0.076 & 1.32 & 1.81 \\
\hline & V5 & 0.87 & 2.53 & 0.014 & 0.028 & 1.39 & 1.56 \\
\hline & V6 & 1.99 & 4.48 & 0.004 & 0.074 & 1.43 & 1.65 \\
\hline \multirow{6}{*}{$100 \mathrm{~cm}$} & V1 & 2.29 & 2.82 & 0.030 & 0.045 & 1.28 & 1.60 \\
\hline & V2 & 0.61 & 1.81 & 0.007 & 0.027 & 1.18 & 1.42 \\
\hline & V3 & 1.92 & 1.52 & 0.026 & 0.025 & 1.32 & 1.55 \\
\hline & V4 & 1.76 & 3.75 & 0.022 & 0.056 & 1.28 & 1.50 \\
\hline & V5 & 0.72 & 1.47 & 0.009 & 0.023 & 1.09 & 1.12 \\
\hline & V6 & 1.40 & 1.98 & 0.003 & 0.025 & 1.21 & 1.33 \\
\hline \multirow{6}{*}{$120 \mathrm{~cm}$} & V1 & 1.70 & 2.14 & 0.021 & 0.037 & 1.22 & 1.60 \\
\hline & V2 & 0.34 & 0.72 & 0.003 & 0.009 & 1.07 & 1.17 \\
\hline & V3 & 1.17 & 0.84 & 0.016 & 0.012 & 1.30 & 1.44 \\
\hline & V4 & 1.27 & 0.83 & 0.016 & 0.012 & 1.21 & 1.50 \\
\hline & V5 & 0.31 & 0.85 & 0.004 & 0.008 & 1.25 & 1.06 \\
\hline & V6 & 1.10 & 0.78 & 0.002 & 0.010 & 1.15 & 1.26 \\
\hline \multicolumn{2}{|c|}{ LSD at 5\% level } & 0.07 & 0.53 & 0.001 & 0.007 & NS & NS \\
\hline
\end{tabular}

\subsubsection{Mean No. Holes / Joint}

The results in Table (2) revealed that the mean no. holes / joint was significantly affected by inter-row spacing in the plant cane and $1^{\text {st }}$ ratoon crops. Growing sugarcane in rows of $120 \mathrm{~cm}$ decreased the mean no. holes / joint by 0.012 and 0.03 in the plant cane and 0.33 and 0.08 in the $1^{\text {st }}$ ratoon, respectively, compared with that recorded in planting sugarcane at 80 and/or $100 \mathrm{~cm}$ inter-row spacing.

Significant differences in mean no. holes / joint among the tested varieties in both plant cane and $1^{\text {st }}$ ratoon. G.T.54-9 was the highest infested variety in both plant cane and $1^{\text {st }}$ ratoon (0.031 and 0.061$)$ respectively. On the other hand, G.2004-27 (in plant cane) 0.007 and G.99-103 (in $1^{\text {st }}$ ratoon) 0.020 were the lowest mean no. holes per joint. Some findings coincide with current results and some others disagree with them. Abu-Dooh (1988) \& Maareg et al. (1993) and Eskander (1996) claimed that plant canes were less susceptible than ratoon.

Mean no. holes / joint was significantly influenced by the interaction between the tested cane varieties and inter-row spacing in the plant cane and $1^{\text {st }}$ ratoon.

\subsubsection{Mean No. Holes / Infested Joint}

The result in Table (2) revealed that the mean no. holes / infested joint was significantly affected by inter-row spacing in the plant cane and $1^{\text {st }}$ ratoon crops. Growing sugarcane in rows of $120 \mathrm{~cm}$ 
Evaluation of Some Promising Sugarcane Varieties for Infestation with Two Sugarcane Borers, Yield and Quality under Different Row Spacing in Luxor Governorate, Egypt

decreased the mean no. holes / infested joint by 0.13 and 0.03 in the plant cane and 0.33 and 0.08 in $1^{\text {st }}$ ratoon, respectively, compared with that recorded in planting sugarcane at 80 and/or $100 \mathrm{~cm}$ interrow spacing.

Average data (over plant cane and $1^{\text {st }}$ ratoon) in Table (2) clarify that, mean no. holes / infested joint insignificantly differed among the varieties.

Table3. Mean no. holes/ stalk, brix \% and sucrose \% of the tested sugarcane varieties as affected by inter-row spacing and their interactions, in the plant cane, PC (2017/18) and its $1^{\text {st }}$ ratoon crop, FR (2018/19).

\begin{tabular}{|c|c|c|c|c|c|c|c|}
\hline \multirow{2}{*}{\multicolumn{2}{|c|}{ Treatments }} & \multicolumn{2}{|c|}{ Mean no. holes/stalk } & \multicolumn{2}{|c|}{ Brix \% } & \multicolumn{2}{|c|}{ Sucrose \% } \\
\hline & & $\mathrm{PC}$ & FR & $\mathrm{PC}$ & FR & $\mathrm{PC}$ & FR \\
\hline \multicolumn{8}{|c|}{ Row spacing } \\
\hline \multicolumn{2}{|c|}{$80 \mathrm{~cm}$} & 0.37 & 1.15 & 18.76 & 18.75 & 14.43 & 15.58 \\
\hline \multicolumn{2}{|c|}{$100 \mathrm{~cm}$} & 0.26 & 0.55 & 19.71 & 19.25 & 16.40 & 16.36 \\
\hline \multicolumn{2}{|c|}{$120 \mathrm{~cm}$} & 0.16 & 0.31 & 19.10 & 18.54 & 15.05 & 15.14 \\
\hline \multicolumn{2}{|c|}{ LSD at $5 \%$ level } & 0.01 & 0.01 & NS & 0.22 & 0.41 & 0.53 \\
\hline \multicolumn{8}{|c|}{ Sugarcane varieties } \\
\hline \multicolumn{2}{|c|}{ G.T.54-9 (V1) } & 0.43 & 1.19 & 19.52 & 18.82 & 15.45 & 15.55 \\
\hline \multicolumn{2}{|c|}{ G.2004-27 (V2) } & 0.11 & 0.44 & 19.23 & 19.20 & 15.62 & 15.75 \\
\hline \multicolumn{2}{|c|}{ G.84-47 (V3) } & 0.36 & 0.65 & 19.61 & 18.93 & 15.26 & 15.94 \\
\hline \multicolumn{2}{|c|}{ G.2003-47 (V4) } & 0.33 & 0.81 & 19.78 & 19.78 & 16.48 & 17.31 \\
\hline \multicolumn{2}{|c|}{ G.99-103 (V5) } & 0.11 & 0.38 & 18.34 & 17.57 & 14.53 & 14.27 \\
\hline \multicolumn{2}{|c|}{ C.57-14 (V6) } & 0.25 & 0.56 & 18.66 & 18.79 & 14.44 & 15.35 \\
\hline \multicolumn{2}{|c|}{ LSD at $5 \%$ level } & 0.01 & 0,07 & 0.85 & 0.52 & 0.83 & 0.52 \\
\hline \multicolumn{8}{|c|}{ Interaction } \\
\hline \multirow{6}{*}{$80 \mathrm{~cm}$} & V1 & 0.58 & 2.08 & 19.36 & 18.87 & 15.03 & 15.58 \\
\hline & V2 & 0.18 & 0.67 & 18.97 & 19.80 & 14.99 & 15.79 \\
\hline & V3 & 0.48 & 1.25 & 19.50 & 19.13 & 13.26 & 16.35 \\
\hline & V4 & 0.45 & 1.31 & 19.75 & 19.83 & 16.20 & 17.18 \\
\hline & V5 & 0.18 & 0.56 & 17.00 & 16.65 & 13.51 & 13.71 \\
\hline & V6 & 0.35 & 1.06 & 17.97 & 18.20 & 13.60 & 14.88 \\
\hline \multirow{6}{*}{$100 \mathrm{~cm}$} & V1 & 0.41 & 0.75 & 19.60 & 19.00 & 16.34 & 16.06 \\
\hline & V2 & 0.10 & 0.50 & 19.61 & 19.60 & 17.11 & 16.63 \\
\hline & V3 & 0.38 & 0.42 & 20.00 & 19.25 & 17.51 & 16.90 \\
\hline & V4 & 0.33 & 0.83 & 20.00 & 19.90 & 17.02 & 17.47 \\
\hline & V5 & 0.12 & 0.39 & 20.00 & 18.10 & 15.08 & 15.00 \\
\hline & V6 & 0.22 & 0.42 & 19.05 & 19.67 & 15.36 & 16.10 \\
\hline \multirow{6}{*}{$120 \mathrm{~cm}$} & V1 & 0.28 & 0.72 & 19.60 & 18.60 & 14.97 & 15.01 \\
\hline & V2 & 0.05 & 0.17 & 19.10 & 18.20 & 14.76 & 14.82 \\
\hline & V3 & 0.22 & 0.28 & 19.33 & 18.40 & 15.02 & 14.57 \\
\hline & V4 & 0.21 & 0.28 & 19.60 & 19.60 & 16.22 & 17.27 \\
\hline & V5 & 0.05 & 0.19 & 18.03 & 17.95 & 15.01 & 14.09 \\
\hline & V6 & 0.16 & 0.22 & 18.95 & 18.50 & 14.35 & 15.06 \\
\hline \multicolumn{2}{|c|}{ LSD at $5 \%$ level } & 0.01 & 0.12 & NS & 0.91 & $\mathrm{NS}$ & NS \\
\hline
\end{tabular}

Mean no. holes / infested joint was insignificantly influenced by the interaction between the tested cane varieties and inter-row spacing in the plant cane and $1^{\text {st }}$ ratoon.

\subsubsection{Mean No. Holes / Stalk}

The results in Table (3) revealed that the mean no. of holes / stalk was significantly affected by interrow spacing in the plant and $1^{\text {st }}$ ratoon crops. Growing sugarcane in rows of $120 \mathrm{~cm}$ decreased the mean no. holes / stalk by 0.21 and 0.1 in the plant cane and 0.84 and 0.24 in $1^{\text {st }}$ ratoon, respectively, compared with that recorded in planting sugarcane at 80 and /or $100 \mathrm{~cm}$ inter-row spacing.

Significant difference in mean no. holes / stalk among the tested varieties over and within both plant cane and $1^{\text {st }}$ ratoon have been detected (Table 3). Average data clear that, G.T. 54-9 was the least tolerant variety recorded the highest mean no. holes / stalk in both plant cane and $1^{\text {st }}$ ratoon $(0.43$ and 1.19), respectively. On the other side, G.2004-27 and G.99-103 (in plant cant) 0.11 and G.99-103 (in $1^{\text {st }}$ ratoon) 0.38 were the lowest mean no. holes per stalk.

Mean no. holes /stalk was significantly influenced by the interaction between the tested cane varieties and inter-row spacing in the plant cane and $1^{\text {st }}$ ratoon. 
Evaluation of Some Promising Sugarcane Varieties for Infestation with Two Sugarcane Borers, Yield and Quality under Different Row Spacing in Luxor Governorate, Egypt

\subsection{Juice Quality Characteristics and Yield}

\subsubsection{Brix Percentage}

Data in Table (3) indicated that brix\% was significant affected by inter-row spacing in $1^{\text {st }}$ ratoon crop only. Growing sugarcane in rows of $100 \mathrm{~cm}$ increased brix $\%$ by 0.5 and $0.71 \%$ in the $1^{\text {st }}$ ratoon compared with that recorded in planting sugarcane at 80 and/or $120 \mathrm{~cm}$ inter-row spacing respectively.

The tested sugarcane varieties differed markedly in the brix \%. The results in Table (3) manifested that G.2003-47 sugarcane variety gave the highest brix $\%$ in the plant cane and $1^{\text {st }}$ ratoon crops. However, the difference in brix \% between G.2003-47 and each G.2004-27, G.84-47 and the commercial variety G.T.54-9 was insignificant, in the plant cane. Meanwhile, it was found that G.99-103 variety had the lowest brix $\%$, in the plant cane and $1^{\text {st }}$ ratoon crops. The differences between the studied varieties with respect to brix value may be mainly due to gene make-up the differences, in the addition to, the surrounding environmental conditions prevailing during the formation period of soluble solids. The same results reported by Galal et al. (2017) and El-Bakry (2018).

The interaction between inter-row spacing and the tested cane varieties was significant in the $1^{\text {st }}$ ratoon crop only.

\subsubsection{Sucrose Percentage}

Data in Table (3) showed that the sucrose\% was significantly affected by inter-row spacing in the plant cane and $1^{\text {st }}$ ratoon crops. Growing sugarcane in rows of $100 \mathrm{~cm}$ increased the sucrose $\%$ by 1.97 and $1.35 \%$ in the plant cane and 0.78 and $1.22 \%$ in $1^{\text {st }}$ ratoon, respectively, compared with that recorded in planting sugarcane at 80 and/or $120 \mathrm{~cm}$ inter-row spacing. These results are in agreement with those obtained by Ahmed et al. (2011) and Pawar et al. (2005).

Table4. Sugar recovery \%, Cane yield/ ton per ha and sugar yield/ ton per ha of the tested sugarcane varieties as affected by inter-row spacing and their interactions, in the plant cane, PC (2017-2018) and its $1^{\text {st }}$ ratoon crop, FR (2018-2019).

\begin{tabular}{|c|c|c|c|c|c|c|c|}
\hline \multirow{2}{*}{\multicolumn{2}{|c|}{ Treatments }} & \multicolumn{2}{|c|}{ Sugar recovery \% } & \multicolumn{2}{|c|}{ Cane yield/ton per ha } & \multicolumn{2}{|c|}{ sugar yield/ ton per ha } \\
\hline & & $\mathrm{PC}$ & FR & $\mathrm{PC}$ & FR & $\mathrm{PC}$ & FR \\
\hline \multicolumn{8}{|c|}{ Row spacing } \\
\hline \multicolumn{2}{|c|}{$80 \mathrm{~cm}$} & 9.27 & 10.45 & 141.51 & 136.54 & 13.10 & 14.29 \\
\hline \multicolumn{2}{|c|}{$100 \mathrm{~cm}$} & 11.01 & 11.10 & 145.20 & 158.78 & 16.01 & 17.63 \\
\hline \multicolumn{2}{|c|}{$120 \mathrm{~cm}$} & 9.81 & 10.05 & 109.01 & 126.02 & 10.64 & 12.67 \\
\hline \multicolumn{2}{|c|}{ LSD at $5 \%$ level } & 0.28 & 0.52 & 26.14 & 12.51 & 2.69 & 1.84 \\
\hline \multicolumn{8}{|c|}{ Sugarcane varieties } \\
\hline \multicolumn{2}{|c|}{ G.T.54-9 (V1) } & 10.09 & 10.40 & 121.31 & 131.96 & 12.26 & 13.74 \\
\hline \multicolumn{2}{|c|}{ G.2004-27 (V2) } & 10.35 & 10.49 & 150.77 & 161.57 & 15.70 & 17.02 \\
\hline \multicolumn{2}{|c|}{ G.84-47 (V3) } & 9.87 & 10.76 & 133.31 & 143.82 & 13.37 & 15.55 \\
\hline \multicolumn{2}{|c|}{ G.2003-47 (V4) } & 11.07 & 11.91 & 128.65 & 144.27 & 14.29 & 17.19 \\
\hline \multicolumn{2}{|c|}{ G.99-103 (V5) } & 9.50 & 9.45 & 149.38 & 148.90 & 13.78 & 14.20 \\
\hline \multicolumn{2}{|c|}{ C.57-14 (V6) } & 9.31 & 10.20 & 108.01 & 112.14 & 10.10 & 11.48 \\
\hline \multicolumn{2}{|c|}{ LSD at $5 \%$ level } & 0.84 & 0.49 & 16.35 & 7.75 & 1.76 & 1.06 \\
\hline \multicolumn{8}{|c|}{ Interaction } \\
\hline \multirow{6}{*}{$80 \mathrm{~cm}$} & V1 & 9.71 & 10.42 & 121.58 & 129.77 & 11.80 & 13.52 \\
\hline & $\mathrm{V} 2$ & 9.78 & 10.36 & 155.85 & 157.20 & 15.24 & 16.28 \\
\hline & V3 & 7.86 & 11.12 & 124.10 & 134.95 & 9.76 & 15.02 \\
\hline & V4 & 10.79 & 11.77 & 137.41 & 142.09 & 14.82 & 16.72 \\
\hline & V5 & 8.84 & 9.15 & 193.67 & 136.82 & 16.90 & 12.50 \\
\hline & V6 & 8.65 & 9.89 & 116.44 & 118.41 & 10.08 & 11.71 \\
\hline \multirow{6}{*}{$100 \mathrm{~cm}$} & V1 & 10.98 & 10.86 & 124.55 & 141.40 & 13.70 & 15.36 \\
\hline & $\mathrm{V} 2$ & 11.76 & 11.27 & 163.61 & 178.05 & 19.26 & 20.08 \\
\hline & V3 & 12.05 & 11.66 & 154.58 & 158.97 & 18.61 & 18.53 \\
\hline & V4 & 11.56 & 12.04 & 143.59 & 161.91 & 16.59 & 19.49 \\
\hline & V5 & 9.57 & 10.05 & 163.27 & 184.93 & 15.56 & 18.67 \\
\hline & V6 & 10.13 & 10.71 & 121.62 & 127.41 & 12.35 & 13.65 \\
\hline
\end{tabular}


Evaluation of Some Promising Sugarcane Varieties for Infestation with Two Sugarcane Borers, Yield and Quality under Different Row Spacing in Luxor Governorate, Egypt

\begin{tabular}{|c|c|c|c|c|c|c|c|}
\hline \multirow{4}{*}{$\mathbf{1 2 0} \mathbf{~ c m}$} & V1 & 9.57 & 9.90 & 117.81 & 124.71 & 11.28 & 12.34 \\
\cline { 2 - 8 } & V2 & 9.50 & 9.83 & 132.86 & 149.48 & 12.61 & 14.69 \\
\cline { 2 - 8 } & V3 & 9.70 & 9.52 & 121.26 & 137.56 & 11.75 & 13.09 \\
\cline { 2 - 8 } & V4 & 10.86 & 11.93 & 104.96 & 128.81 & 11.45 & 15.36 \\
\cline { 2 - 8 } & V5 & 10.07 & 9.16 & 91.21 & 124.95 & 8.89 & 11.44 \\
\cline { 2 - 8 } & V6 & 9.13 & 9.99 & 85.98 & 90.62 & 7.86 & 9.08 \\
\hline \multicolumn{2}{|c|}{ LSD at 5\% level } & NS & NS & 28.31 & 13.42 & 3.05 & NS \\
\hline
\end{tabular}

The results indicated that G.2003-47 promising variety gave the highest sucrose\% (16.48 and $17.31 \%$ ) in the plant cane and $1^{\text {st }}$ ratoon, respectively, compared with the other varieties. Meanwhile, it was found that C.57.14 and G.99-103 varieties had the lowest sucrose \% in the plant cane and $1^{\text {st }}$ ratoon. Such varietal differences among cane genotypes in sucrose \% were reported by El-Geddawy, et al., 2015 \&, Galal, et al., 2017.

Sucrose \% was insignificantly influenced by the interaction between the tested cane varieties and interrow spacing in the plant cane and $1^{\text {st }}$ ratoon.

\subsubsection{Sugar Recovery Percentage}

Data in Table (4) showed that the sugar recovery $\%$ was significantly affected by inter-row spacing in the plant cane and $1^{\text {st }}$ ratoon crops. Growing sugarcane in rows of $100 \mathrm{~cm}$ increased the sugar recovery $\%$ by 1.83 and $1.29 \%$ in the plant cane and 0.65 and $1.05 \%$ in $1^{\text {st }}$ ratoon, respectively, compared with that recorded in planting sugarcane at 80 and /or $120 \mathrm{~cm}$ inter-row spacing. These results are in harmony with that found by Sharar, et al., 2000 and Asokan, et al., 2005.

Sugar recovery\% affected significantly by the tested sugarcane varieties, G.2003-47 promising variety gave the highest sugar recovery \% (11.07 and 11.91\%) in the plant cane and $1^{\text {st }}$ ratoon crops, respectively. Meanwhile, there was insignificant difference in sugar recovery $\%$ obtained from G.2003-47 and G.2004-27 grown as a plant cane crop. However, the difference in sugar recovery \% between G.2004-27 promising variety and each the commercial variety G.T.54-9 and G.84-47 variety was insignificant, in the plant cane and $1^{\text {st }}$ ratoon. These finding are in accordance with those obtained by Galal, et al. (2017) and El-Bakry (2018)

Sugar recovery\% was insignificantly influenced by the interaction between the tested cane varieties and inter-row spacing in the plant cane and $1^{\text {st }}$ ratoon crops, there was insignificant variance between G.2003-47 and each G.2004-27 and G.84-47 varieties in sugar recovery \% in sugarcane planted in rows spaced at $100 \mathrm{~cm}$, in the plant and $1^{\text {st }}$ ratoon crops.

\subsubsection{Cane Yield/Ton Per Ha}

Data in Table (4) showed that cane yield/ha was significantly affected by inter-row spacing in the plant cane and its $1^{\text {st }}$ ratoon crops. Planting sugarcane in rows of $100 \mathrm{~cm}$ apart increased the cane yield/ha by 3.69 and 36.19 ton of canes/ha over that gained in case of growing sugarcane in rows of $80 \mathrm{and} / \mathrm{or} 120 \mathrm{~cm}$ space, respectively, in the plant cane, corresponding to 22.24 and 32.76 ton of canes/ha in $1^{\text {st }}$ ratoon. The difference between 80 and $100 \mathrm{~cm}$ in their influence on cane yield/ha was insignificant, in the plant cane. Similar results were given by Abd El-Lattief (2016).

Promising sugarcane variety G.2004-27 exhibited the superiority in cane yield recording significant increases amounted to $29.46,17.46,22.12$ and 42.76 tons/ha higher than those produced by G.T.54-9, G.84-47, G.2003-47 and C.57-14 varieties respectively, in the plant cane, corresponding to 29.61, $17.75,17.30,12.67$ and 49.43 tons/ha in $1^{\text {st }}$ ratoon cane. However, the difference in this trait between G.84-47 and G.2003-47 was insignificant, in the plant cane. Varietal differences in cane yield were observed by El-Sogheir \& Abd El- Fattah (2009) and Fahmy, et al. (2017).

Cane yield was significantly influenced by the interaction between inter-row spacing and tested cane varieties in the plant cane and $1^{\text {st }}$ ratoon. The difference between G.T.54-9 and G.2003-47 in cane yield/ton per ha was insignificant when they were planted in rows of $120 \mathrm{~cm}$ spaced, in the plant cane as well as at 80 and $120 \mathrm{~cm}$ in $1^{\text {st }}$ ratoon cane. However, G.2003-47 surpassed G.T.54-9 in this trait when they were planted in rows of 80 and $100 \mathrm{~cm}$ spaced.

\subsubsection{Sugar Yield/Ton Per Ha}

Data illustrated in Table (4) cleared that the sugar yield / ton per ha was significantly affected by inter-row spacing in the plant cane and its $1^{\text {st }}$ ratoon crops. Growing sugarcane in rows of $100 \mathrm{~cm}$ 
apart increased the sugar yield by 2.91 and 5.37 ton of sugar/ha over that gained in case of growing sugarcane in rows of 80 and/or $120 \mathrm{~cm}$ space, respectively, in the plant cane, corresponding to 3.34 and 4.96 ton of sugar/ha in $1^{\text {st }}$ ratoon. Similar results were obtained by El-Geddawy, et al. (2002) and Pawar, et al. (2005).

Promising sugarcane variety G.2004-27 exhibited the superiority in sugar yield recording significant increases amounted to $3.90,2.33,1.92$ and 5.60 tons/ha higher than those produced by G.T.54-9, G.84-47, G.2003-47 and C.57-14 varieties respectively, in the plant cane. On the other hand, G.2003-47 exhibited the superiority in sugar yield recording insignificant increases amounted to 3.67, 1.64, 2.99 and 5.71 tons/ha higher than those produced by G.T.54-9, G.84-47, G.99-103 and C.57-14 varieties respectively in $1^{\text {st }}$ ratoon. However, the difference in this trait between 'G.84-47' and 'G.2003-47' was insignificant, in the plant cane. Such varietal differences were reported by Abd ElLattief (2016) and El-Bakry (2018).

Sugar yield ton/ha was insignificantly influenced by the interaction between the tested cane varieties and inter-row spacing in the $1^{\text {st }}$ ratoon. These results are in agreement with those reported by ElSogheir and Abd El-Fattah (2009).

\section{CONCLUSiON}

Under conditions of this work, the promising sugarcane variety G.2004-27 was highest tolerance in all studied measurements of infestation by S.cretica and C. agamemnon in both seasons. Also, it recorded the highest values for cane and sugar yield /ton per ha in the plant cane and $1^{\text {st }}$ ratoon crops in rows spaced at $100 \mathrm{~cm}$.

\section{REFERENCES}

[1] Abd El-Lattief, E.A. (2016). Yield and yield attributes of sugarcane as affected by some crop management treatments. I. J. Res. Eng. Appl. Sci. 6 (12): 11-19.

[2] Abu-Dooh, A.M. (1988). Relationship between sugarcane borer, Chilo Agamemnon Blez. attack on incidence, intensity and loss of the sugarcane yield. Assiut J. Agric. Sci., 28(2): 9-15.

[3] Ahmed, Z.A., A.M. Ahmed and M.S.H. Osman (2011). Optimum inter-row spacing and number of ploughings for two promising sugarcane varieties. Egypt. J. Agric. Res., 89 (1), 301-316.

[4] A.O.A.C. (1995) Association of official analytical chemists. Official methods of analysis, 16th Ed. Int., Washington, D. C., USA.

[5] Asokan, S., A.N. Murthi and M. Mahadevaswamy (2005). Effect of nitrogen level and row spacing on yield, CCS and nitrogen uptake in different sugarcane varieties. Sugar Technol., 7(3): 44-47.

[6] Chitkala Devi, T., M. Bharatha Lakshmi and N.V. Naidu (2005). Response of New Sugarcane Genotypes to Wide Row Spacing. Sugar Technol., 7(4): 154-156.

[7] Eid, M. A., H. A. El-Shabrawy, M. F. Maarg and R. S. Yakoub (2005). Relative susceptibility of some new promising sugarcane varieties to the pink borer, Sesamia cretica Lederer and the purple-lined borer, Chilo agamemnon Bles. Bull. Ent. Soc. Egypt, 82: 229-243.

[8] El-Bakry, A. (2018) Effect of row spacing on some sugarcane varieties yield and juice quality. J. Biol. Chem. Environ. Sci., 13(2): 105-120.

[9] El-Geddawy, I.H.; D.G. Darweish; A.A. El-Sherbiny and E.E.A. El-Hady (2002). Effect of row spacing and number of buds/ setts on growth characters of ratoon crops for some sugarcane varieties. Pakistan Sugar J., 17(3): 7-14.

[10] El-Geddawy I.H.; Dalia I.H. El-Geddawy; B.S.I. Makhlouf and M.A. Bekheet (2015). Performance of some sugar cane promising varieties under different seed sett rates and potassium fertilization. Int. J. Curr. Microbiol. Appl. Sci., 4 (11): 92-110.

[11] El-Sherif, S.I. (1962). Studies on the corn borers in Alexandria district, Egypt, Chilo agamemnon Wilk. (Lepidoptera: Crambidae), Pyrausa nubilalis Hbn. (Lepidoptera: Pyraustidae), and Sesamia cretica Led. (Lepidoptera: Noctuidae). Unpublished M.Sc. Thesis, Alexandria Univ., Egypt, 199 pp.

[12] El-Sogheir, K.S. and A.I. Abd El-Fattah (2009). Evaluation of some promising sugar cane varieties under different row spacing. J. Biol Chem. Environ. Sci, 4(1): 285-318.

[13] Elwan, E.A., A.A. Abazied, L.A. Youssef and H.E.A. Sakr (2008). Influence of some agricultural practices on the infestation with lesser sugarcane borer, Chilo agamemnon Bles. in the autumn plant cane and its 1st ratoon in upper Egypt. Egypt. J. Agric. Res., 86(5): 1801-1826. 
[14] Eskandar, R.A. (1996). Evaluation of some sugarcane genotypes for infestation with some animal and insect pests. M.Sc. Thesis, Fac. Agric., Zagazig Univ., Egypt.

[15] Fahmy, A.M.; M.A.M. Osman and M.O.A. Galal (2017). Yield, Quality and Natural Infestation with Insect and Disease of Four Sugarcane Varieties as Affected by Different Levels of Potassium Fertilization. J. Plant Prot. and Path., Mansoura Univ., 8 (12): 687 - 693.

[16] Galal, M.O.A., A.M. Abou-Salama, E.A. Teama and A.Z. Ahmed (2015). Yield response of late planted spring sugarcane to direct set sowing and transplanting. Sci. J. King Faisal Univ. (Basic Appl. Sci.), 16(1): 75-94.

[17] Galal, M.O.A., M.A.M. Osman, A.M. Fahmy and A. El-Mohamed (2017). Performance of some sugarcane genotypes under different planting methods and natural infestation with insects and diseases. Egypt. J. Plant Breed. 21(4):843-859.

[18] Maareg, M.F., A.M. Abu-Dooh and A.M. Ebieda (1993). Varietal resistance to purple - lined borer Chilo agamemnon Bles. and relative differential yield loss of certain local sugarcane varieties in Egypt. Annals of Agric. Sci., Moshtohor, 31(1): 517-527.

[19] Maqsood, M., M. Iqbal and M. Tayyab (2005). Comparative Productivity Performance of Sugarcane (Saccharum officinarum, L.) Sown in Different Planting Patterns at Farmer's Field. Pakistan J. Agric. Sci., $42(3-4)$ 25-28.

[20] Mehareb, E.M., M.A.M. Osman and A.M. Fahmy (2018). Screening sugarcane genotypes for the lesser sugarcane borer, Chilo agamemnon Bels., and four main diseases resistance in Egypt. Egypt. J. Plant Breed. 22(4):659- 683.

[21] Mendes, A.C.; P.S. Botelho and N. Macedo (1980). Correlation between the intensity of infestation and population index of the sugarcane borer, Diatraea sacchralis (Fabr.) Proc. ISSCT, 17, Bull. 8p.

[22] Pawar, M.W., D.B. More, V.T. Amodkar and S. Joshi (2005). Effect of interesting spacing on sugarcane yield and quality. Ind. J. Sugar Tech., 7(1): 87-89.

[23] Salman, A.M.A., A.A. Abazied and A.M. Fahmy (2014). Effect of some cultural practices on the infestation level of Chilo agamemnon Bles., infesting sugarcane varieties at Luxor Governorate. Middle East J. Agric. Res., 3(3): 569-575.

[24] Sharar, M.S., M. Ayub, M.A. Choudhry, M.M.Z. Amin and M.M. Khalid (2000). Morph qualitative traits of sugarcane varieties as influenced by seeding density. Pak. J. Biol. Sci., 3: 1156-1157.

[25] Snedecor, G.W. and W.G. Cochran (1981). Statistical Methods. Seventh Ed. Iowa State Univ. Press, Ames, Iowa, USA.

[26] Tohamy, T.H. (1999). Ecological studies on certain sugarcane pests in Middle Egypt. Ph.D. Thesis, Fac. Agric., El-Minia Univ., Egypt.

[27] Yadav, R.L. and R.K. Sharma (1980). Effect of nitrogen level and harvesting date on quality characteristics and yield of four sugarcane genotypes. Indian J. Agric. Sci. 50: 581-589.

Citation: Fahmy, A.M., et.al.," Evaluation of Some Promising Sugarcane Varieties for Infestation with Two Sugarcane Borers, Yield and Quality under Different Row Spacing in Luxor Governorate, Egypt", International Journal of Research Studies in Zoology, vol. 5, no. 3, p. 11-21, 2019. DOI: http://dx.doi. org/10.20431/2454-941X.0503002

Copyright: (C) 2019 Authors. This is an open-access article distributed under the terms of the Creative Commons Attribution License, which permits unrestricted use, distribution, and reproduction in any medium, provided the original author and source are credited. 